\title{
Correlation among cirrus ice content, water vapor and temperature in the TTL as observed by CALIPSO and Aura/MLS
}

\author{
T. Flury ${ }^{1}$, D. L. Wu ${ }^{1,2}$, and W. G. $\operatorname{Read}^{1}$ \\ ${ }^{1}$ Jet Propulsion Laboratory, California Institute of Technology, Pasadena, California, USA \\ ${ }^{2}$ NASA-Goddard Space Flight Center, Greenbelt, Maryland, USA \\ Correspondence to: T. Flury (thomas.flury@jpl.nasa.gov) \\ Received: 23 July 2011 - Published in Atmos. Chem. Phys. Discuss.: 8 September 2011 \\ Revised: 23 December 2011 - Accepted: 5 January 2012 - Published: 16 January 2012
}

\begin{abstract}
Water vapor in the tropical tropopause layer (TTL) has a local radiative cooling effect. As a source for ice in cirrus clouds, however, it can also indirectly produce infrared heating. Using NASA A-Train satellite measurements of CALIPSO and Aura/MLS we calculated the correlation of water vapor, ice water content and temperature in the TTL. We find that temperature strongly controls water vapor (correlation $r=0.94$ ) and cirrus clouds at $100 \mathrm{hPa}$ $(r=-0.91)$. Moreover we observe that the cirrus seasonal cycle is highly $(r=-0.9)$ anticorrelated with the water vapor variation in the TTL, showing higher cloud occurrence during December-January-February. We further investigate the anticorrelation on a regional scale and find that the strong anticorrelation occurs generally in the ITCZ (Intertropical Convergence Zone). The seasonal cycle of the cirrus ice water content is also highly anticorrelated to water vapor $(r=-0.91)$ and our results support the hypothesis that the total water at $100 \mathrm{hPa}$ is roughly constant. Temperature acts as a main regulator for balancing the partition between water vapor and cirrus clouds. Thus, to a large extent, the depleting water vapor in the TTL during DJF is a manifestation of cirrus formation.
\end{abstract}

\section{Introduction}

Water vapor $\left(\mathrm{H}_{2} \mathrm{O}\right)$ is a key constituent of the Earth atmosphere and climate system. It is the dominant greenhouse gas and has important impacts on atmospheric circulations through latent heat exchanges and redistribution of energy (Schneider et al., 2010). As a source of clouds, water vapor has an indirect effect on the surface longwave and shortwave radiation budget.
Water vapor is also important for the radiative balance and chemistry in the stratosphere (de F. Forster and Shine, 1999). An increase in stratospheric water vapor tends to cool the stratosphere due to more longwave emission to space. Recent decadal records show that stratospheric water vapor has been increasing (Solomon et al., 2010; Rosenlof et al., 2001) and it is still under debate which processes regulate the amount of $\mathrm{H}_{2} \mathrm{O}$ that reaches the stratosphere (Chae et al., 2011). However, it is widely accepted that water vapor enters the stratosphere through the tropical tropopause layer (TTL), which is the layer on top of the main cumulus outflow. The TTL extends approximately from $14 \mathrm{~km}(p=150 \mathrm{hPa}$, $\Theta=355 \mathrm{~K})$ to $18.5 \mathrm{~km}$ altitude $(70 \mathrm{hPa}, 425 \mathrm{~K})$ (Fueglistaler et al., 2009) representing a mixed layer having both tropospheric and stratospheric characteristics. The bottom of the TTL is usually defined by the level of zero net radiative heating. Above this level air tends to rise by radiative heating whereas below, it tends to sink. The top of the TTL is the maximum height of overshooting convection.

Water vapor in the TTL primarily comes from convective processes. The interplay between transport and freeze-drying controls the amount of $\mathrm{H}_{2} \mathrm{O}$ lifted into the stratosphere (Read et al., 2008). Yang et al. (2010) suggest that $\mathrm{H}_{2} \mathrm{O}$ from overshooting convection can be radiatively lifted up to the stratosphere which is supported by measurements of Grosvenor et al. (2007) and Corti et al. (2008). Thus stratospheric $\mathrm{H}_{2} \mathrm{O}$ is closely linked to convection and vertical ascent in the TTL.

The ascent of TTL air is to a great extent regulated by temperature and cirrus clouds which provide the necessary radiative heating to balance the adiabatic cooling produced by the slow ascent of air which enters the stratosphere (Jensen et al., 2010). Cirrus above convective cumulus clouds prevail much longer in the atmosphere than the anvils below (Garrett et al., 
2004) and have a warming effect on the surface (Jensen et al., 2010). Wang et al. (1996) already stated that cirrus clouds are more frequent during Northern Hemisphere $(\mathrm{NH})$ winter which is also the season for lowest TTL water vapor volume mixing ratios and lowest temperatures. Dessler et al. (2006) showed by using ICESat measurements that thin TTL cirrus occur frequently between $20^{\circ} \mathrm{S}$ and $30^{\circ} \mathrm{N}$ with distinct maxima over regions of intense convection. Since water vapor and cirrus have opposite effects (Solomon et al., 2010) on surface warming it is critical to know the TTL water budget and the balance between ice and vapor.

Randel et al. (2004) showed that temperature and water vapor are correlated $(r=0.73)$ in the TTL using NCEP temperatures and UARS/HALOE satellite water vapor data. In this study we further investigate the roles of temperature in regulating the water partition between vapor and ice, not only for the TTL but also on a regional basis. We seek to better quantify the amount of cirrus clouds that can serve as a reservoir for TTL water vapor. For this puropse we use data from the NASA A-Train satellite instruments MLS and CALIOP and determine the correlation of water vapor, cirrus cloud fraction and ice water content in the TTL in the years 20062011. Section 2 presents the data and method whereas Sect. 3 lays out the results from the correlation studies. In Sect. 4 we discuss our findings and conclude in Sect. 5.

\section{Data and method}

In this study we use water vapor $\left(\mathrm{H}_{2} \mathrm{O}\right)$, temperature $(T)$ and cloud data from the NASA A-Train satellite instruments MLS (Microwave Limb Sounder) on Aura and CALIOP (Cloud-Aerosol Lidar with Orthogonal Polarization) on CALIPSO (Cloud-Aerosol Lidar and Infrared Pathfinder Satellite Observation) respectively. MLS is a passive microwave radiometer that scans through the Earth's limb whereas CALIOP transmits a laser pulse and collects reflected radiation with a telescope. The utilized data cover the time period from June 2006 (start of CALIPSO) to February 2011. CALIPSO and Aura fly in sun-synchronous orbits and follow each other closely to measure profiles in same regions and at same local solar times.

MLS $\mathrm{H}_{2} \mathrm{O}$ is retrieved from $316 \mathrm{hPa}$ to $0.002 \mathrm{hPa}$ from $82^{\circ} \mathrm{S}$ to $82^{\circ} \mathrm{N}$. We use daily version 2.2 data which have been validated by Read et al. (2007). MLS has a horizontal resolution of $200-300 \mathrm{~km}$ along track, $7 \mathrm{~km}$ across track and $3-4 \mathrm{~km}$ in the vertical. The fields are averaged and mapped onto a $4^{\circ}$ latitude and $8^{\circ}$ longitude grid. For this study we use the vertical levels of $147 \mathrm{hPa}, 121 \mathrm{hPa}, 100 \mathrm{hPa}, 83 \mathrm{hPa}$, $68 \mathrm{hPa}, 56 \mathrm{hPa}, 46 \mathrm{hPa}, 38 \mathrm{hPa}, 32 \mathrm{hPa}, 26 \mathrm{hPa}$ and $22 \mathrm{hPa}$ but the study focuses on $100 \mathrm{hPa}$ in the tropics. The precision and accuracy of $\mathrm{H}_{2} \mathrm{O}$ at $100 \mathrm{hPa}$ is $10 \%$ and $8 \%$ respectively ( $\operatorname{Read}$ et al., 2007). The MLS temperature product is retrieved from $316 \mathrm{hPa}$ to $0.001 \mathrm{hPa}$ and interpolated on the same horizontal grid as water vapor for the purpose of the study. It has a vertical resolution of about $5 \mathrm{~km}$ at $100 \mathrm{hPa}$ decreasing to $3 \mathrm{~km}$ in the middle stratosphere. The precision at $100 \mathrm{hPa}$ is $0.8 \mathrm{~K}$ whilst the uncertainty is about $2 \mathrm{~K}$ (warm bias to other instruments) (Schwartz et al., 2008). MLS provides also ice water content (IWC) profiles but for this study we chose CALIOP because it is more sensitive to thin TTL cirrus clouds, which are the center of interest of the article.

CALIPSO cloud occurrence frequency and IWC level 2 data are of version 3. The data have an original horizontal resolution of $5 \mathrm{~km}$ and $60 \mathrm{~m}$ in the vertical (Winker et al., 2007). We binned the profiles to the coarser MLS horizontal grid described above. The interpolated vertical axis has a higher resolution than the one from MLS since we added at least one level in between every MLS level. For the TTL we thus obtain the levels $147 \mathrm{hPa}, 140 \mathrm{hPa}, 130 \mathrm{hPa}, 121 \mathrm{hPa}$, $110 \mathrm{hPa}, 100 \mathrm{hPa}, 90 \mathrm{hPa}$ and $83 \mathrm{hPa}$. Only nighttime cloud data is used for the TTL cloud analysis because of excessive noise during daytime (Wu et al., 2011). IWC profiles are based on a parameterization of cirrus extinction. The validation of extinction measurements indicates an accuracy better than $10 \%$. However, the uncertainty in the CALIPSO IWC parameterization is not determined, since there are no independent measurements to compare with (D. Winker, personal communication, 2011).

In the following analysis we use daily Aura/MLS $\mathrm{H}_{2} \mathrm{O}$ and $T$ data. Monthly and seasonal averages are determined out of the daily satellite data and used for the correlation studies. The covered time period consists of 57 months which makes a total of 19 seasons (DJF, MAM, JJA, SON). Hence the main results of our study rely on the 19-season time series whilst only one result is based on the daily data, namely the correlation of temperature and water vapor in Sect. 3.1.

\section{Results}

\subsection{Water vapor dependence on temperature}

Air masses entering the stratosphere in the tropics must pass through the low temperature at the tropopause with substantial dehydration. This was first recognized by Brewer (1949) after he had observed surprisingly low water vapor concentrations in the lower stratosphere. The process of temperature dependent dehydration can be observed in the so called atmospheric tape recorder (Mote et al., 1996). The variations in TTL water vapor are slowly carried upward into the stratosphere and the signal is observable from $100 \mathrm{hPa}$ to about $10 \mathrm{hPa}$.

In order to determine to what extent tropical $100 \mathrm{hPa}$ temperatures control tropical and subtropical water vapor we calculated the correlation of the daily zonal mean water vapor and the daily $100 \mathrm{hPa}$ tropical zonal mean temperature $\left(8^{\circ} \mathrm{S}\right.$ to $8^{\circ} \mathrm{N}$ ). The calculation was made for the latitudes $40^{\circ} \mathrm{S}$ to $40^{\circ} \mathrm{N}$ at each pressure level from the upper troposphere to the mid stratosphere using Aura/MLS $\mathrm{H}_{2} \mathrm{O}$ and $T$ time series from August 2004 (start of Aura/MLS) to February 2011. 
Since water vapor is transported upward and poleward from the tropics by the Brewer-Dobson circulation (BDC) we expect $\mathrm{H}_{2} \mathrm{O}$ to be lagged in phase with tropical $100 \mathrm{hPa}$ temperatures at higher altitudes and higher latitudes. On account of this transport we determine the time lag (in weeks) in order to find the maximum correlation of tropical $T$ and $\mathrm{H}_{2} \mathrm{O}$.

The upper plot in Fig. 1 shows the maximum correlation of zonal mean water vapor and tropical $100 \mathrm{hPa}$ temperatures between $150 \mathrm{hPa}$ and $20 \mathrm{hPa}$ as a function of time lag displayed in the bottom plot. There is high correlation inside the tropics up to $20 \mathrm{hPa}$ due to the rising water vapor (atmospheric tape recorder). The time lag is between 1 week at $100 \mathrm{hPa}(\sim 16.4 \mathrm{~km})$ and 21 weeks at $56 \mathrm{hPa}(\sim 20.1 \mathrm{~km})$ which corresponds to an average vertical ascent rate of about $0.3 \mathrm{~mm} \mathrm{~s}^{-1}$ between the two levels, which is similar to results obtained by Schoeberl et al. (2008). Poleward transport is much faster and happens over a few weeks. The time lag at $40^{\circ} \mathrm{N}$ and $100 \mathrm{hPa}$ is 7 weeks whilst the time lag at the same pressure level at $40^{\circ} \mathrm{S}$ is 14 weeks which means that the time-mean transport toward the Southern Hemisphere is slower. This is in agreement with the known characteristics of the BDC and the tropical pipe (Plumb, 1996). The correlation decreases with altitude and latitude because of mixing with other air masses and in situ water vapor production by the oxidation of methane $\left(\mathrm{CH}_{4}\right)$.

But the main result here is that the $100 \mathrm{hPa}$ tropical temperature determines a large portion of lower stratospheric water vapor and its signal is carried upward and poleward with the characteristic time scales of the BDC. Randel et al. (2004) found a maximum correlation coefficient of 0.73 using UARS/HALOE water vapor and NCEP temperatures at $100 \mathrm{hPa}$. In this study the maximum value is 0.94 . Aura/MLS data have a more uniform sampling than HALOE (HALOE took about 1 month to sample 1 latitude band compared to 1 day for MLS), which may explain the higher MLS correlation coefficients.

\subsection{Seasonal cycle of water vapor and cirrus clouds}

It is important to quantify how much of the seasonal cycle of $\mathrm{H}_{2} \mathrm{O}$ in the TTL is due to a varying supply from below or due to regulation by local temperature. In order to answer this question we utilize CALIOP cirrus cloud data. CALIOP can detect thin and subvisible clouds in the TTL and lower stratosphere.

Figure 2 shows a composite map of CALIOP cirrus cloud fraction (contours 5-40\%) and MLS water vapor (color 2.5$5 \mathrm{ppm}$ vmr) at $100 \mathrm{hPa}$ averaged over $5 \mathrm{yr}$ of the $\mathrm{NH}$ winter months December, January and February (DJF) on the top and the NH summer months June, July and August (JJA) on the bottom. For DJF significant cloud cover is found over land (South America, Africa, Northern Australia) in the Inter Tropical Convegence Zone (ITCZ) and over the maritime continent (Indonesia) and the Tropical West Pacific (TWP).
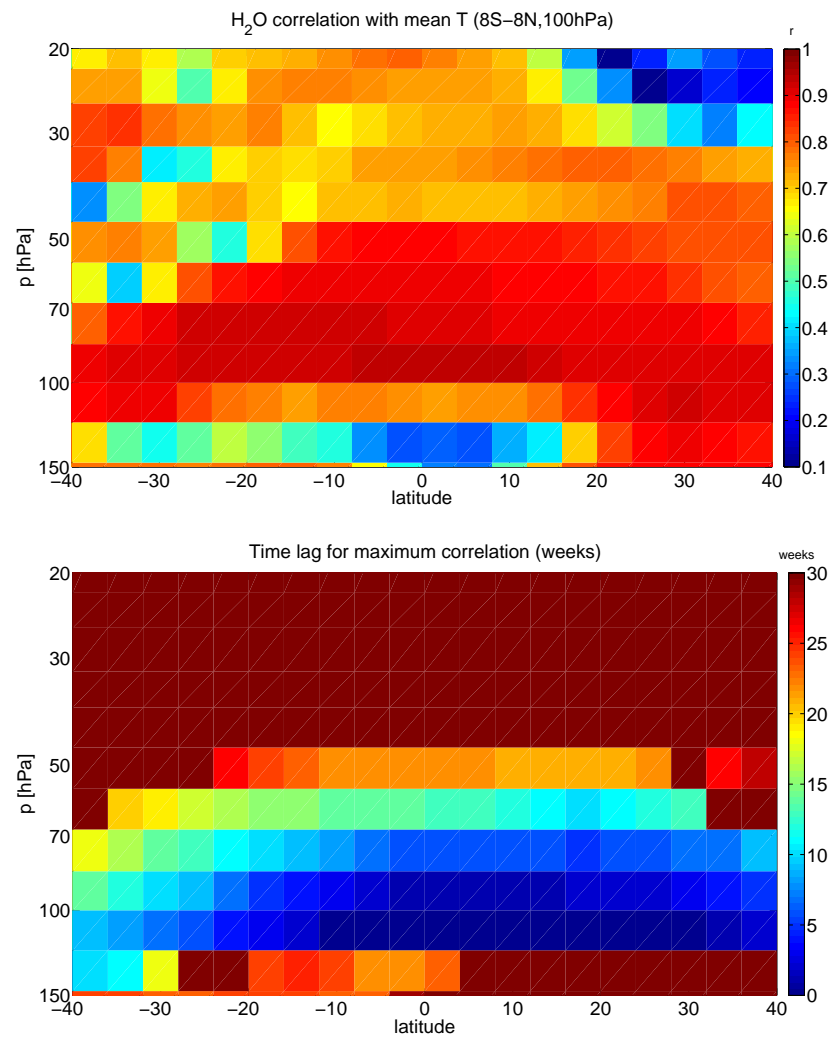

Fig. 1. Maximum correlation of MLS tropical zonal mean $100 \mathrm{hPa}$ temperatures $\left(8^{\circ} \mathrm{S}-8^{\circ} \mathrm{N}\right)$ and MLS zonal mean water vapor at each latitude and pressure level on top. Maximum correlation is found by shifting the water vapor time series by a certain time lag (in weeks) displayed in the bottom plot. The correlation is high $(r>0.7)$ throughout the lower stratosphere from Equator to midlatitudes. Upward and poleward transport can be identified by the increasing time lag in regions where $r$ is still high. Poleward transport is faster than upward and also faster in the Northern Hemisphere.

The TWP is known for its coldest tropopause and is thought to be the region where water vapor is freeze-dried to the lowest values according to saturation vapor pressure before it eventually enters the stratosphere through slow ascent (Gettelman et al., 2002; Fueglistaler et al., 2009). This region corresponds also to the lowest TTL water vapor values (dark blue $\sim 2.5 \mathrm{ppm}$ ).

The JJA map on the bottom of Fig. 2 shows much higher water vapor values in the tropics (please notice the different color scale 3.5-6 ppm vmr) and especially in the subtropical monsoon regions over Asia and America. This is the source region of high water vapor values which are later distributed over the globe and eventually enter the stratosphere visible as ascending branch of high $\mathrm{H}_{2} \mathrm{O}$ in the atmospheric tape recorder (Mote et al., 1996). The higher temperatures lead to less cirrus cloud cover, except over Asia where convection is strong during the monsoon season and brings a lot of water vapor and ice into the TTL. 

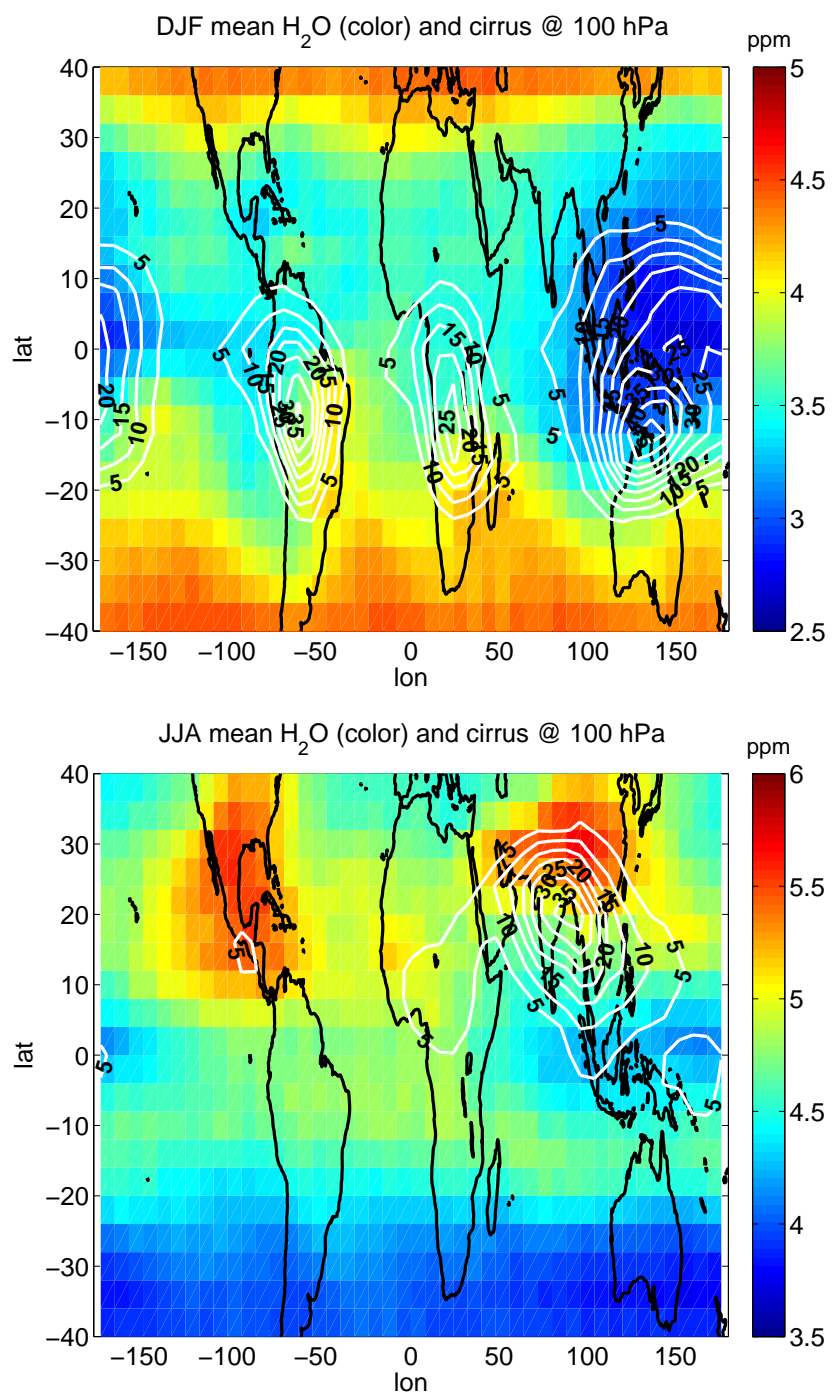

Fig. 2. Seasonal average of cirrus cloud fraction (contours in \%) and water vapor (color) at $100 \mathrm{hPa}$ in DJF (top) and JJA (bottom). Maximum cirrus cloud fraction occurs in DJF at the same time as minimum water vapor values, especially over Indonesia. During JJA water vapor is high and cirrus shift northward into the monsoon regions.

The Brewer-Dobson circulation (BDC) distributes TTL water vapor from the tropics poleward into the lower stratosphere. This transport can be seen in a zonal mean water vapor time series on the $100 \mathrm{hPa}$ level which is plotted in Fig. 3 together with monthly zonal mean cirrus cloud fraction at $100 \mathrm{hPa}$ from $40^{\circ} \mathrm{S}$ to $40^{\circ} \mathrm{N}$. Monthly mean $\mathrm{H}_{2} \mathrm{O}$ is shown in color from $2 \mathrm{ppm}$ to $6 \mathrm{ppm}$ volume mixing ratio whereas contours of $1,6,11$ and $16 \%$ indicate cloud fraction. Both quantities show a significant seasonal cycle with $\mathrm{H}_{2} \mathrm{O}$ minima and cloud fraction maxima occurring in the same season (DJF). Water vapor maxima can be found at about $25^{\circ} \mathrm{N}$ in October. $\mathrm{H}_{2} \mathrm{O}$ is very low in 2008 and 2009 due to ENSO (La Niña) and QBO occurring in phase (Liang et al., 2011)

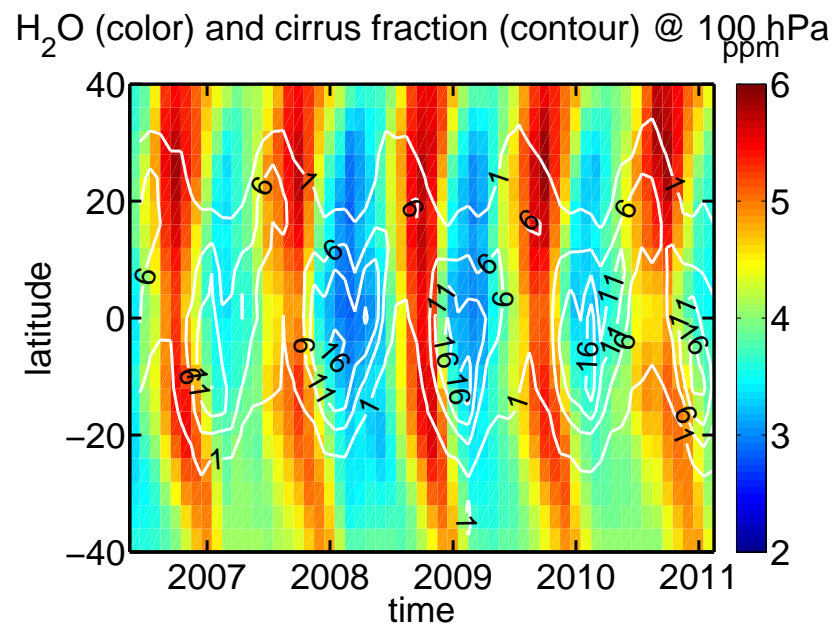

Fig. 3. Time series of zonal mean water vapor (color) and cirrus cloud fraction (contours in $\%$ ) at $100 \mathrm{hPa}$ displayed from $40^{\circ} \mathrm{S}$ to $40^{\circ} \mathrm{N}$. Poleward transport of high and low $\mathrm{H}_{2} \mathrm{O}$ out of the tropics can be identified along lines of similar color. Lower $\mathrm{H}_{2} \mathrm{O}$ in 2008 and 2009 is due to ENSO-La Niña and QBO being in phase. Maximum cloud fraction occurs at the same period as minimum water vapor.

which led to colder TTL temperatures associated with faster BDC upwelling. Significant cirrus cloud fraction is found up to $35^{\circ} \mathrm{N}$. The highest cirrus fraction occurs during winter when water vapor is low. The poleward transport of $\mathrm{H}_{2} \mathrm{O}$ can be identified to be faster to the $\mathrm{NH}$ and slower to the $\mathrm{SH}$ (evident from the steeper bend of the surfaces of same color to the north).

\subsection{Anticorrelation of water vapor and cirrus clouds}

Figures 2 and 3 clearly suggest that cirrus cloud fraction and water vapor are anticorrelated. In order to quantify the relation between cirrus clouds and water vapor at $100 \mathrm{hPa}$ we utilize cirrus ice water content (IWC), which is also measured by CALIOP. IWC and cirrus cloud fraction are nearly perfectly correlated $(r=0.99)$ hence the results we show with IWC would be the same if cirrus cloud fraction would be used. However, IWC has a more useful meaning on the amount of water measured. Seasonal averages of $100 \mathrm{hPa}$ $\mathrm{H}_{2} \mathrm{O}$ and IWC are analyzed to derive their relationship in the TTL. The covered 5-yr time period consists of a total of 19 data points at each location which are used for deriving the correlation.

Figure 4 shows the correlation map of water vapor $\left(\mathrm{H}_{2} \mathrm{O}\right)$ and ice (IWC) at $100 \mathrm{hPa}$. The coefficients are close to $-1 \mathrm{in}$ side the tropics over land as well as over ocean. However, the anticorrelation is higher over Indonesia and the Pacific Ocean than over South America. Convection has a pronounced diurnal cycle over land which is absent over ocean (Hong et al., 2006). This may explain the differences in correlation over 
land and ocean since we only use nighttime CALIPSO measurements. The correlation is mainly positive north of $10^{\circ} \mathrm{N}$. This reflects the influence of tropical tropospheric air and stems mostly from the clear seasonal cycle of convection in these regions which only brings significant amounts of ice into the TTL during the monsoon season. We will discuss this observation in Sect. 4. However, for the rest of the study we will leave out latitudes north of $8^{\circ} \mathrm{N}$ and define three regions for the TTL analysis. The dashed boxes in Fig. 4 highlight the defined regions Indonesia, Africa and South America.

An increase in TTL temperatures increases $\mathrm{H}_{2} \mathrm{O}$ but decreases IWC. Knowledge of the balance of water vapor and ice is important. In order to investigate this balance we analyze the amounts of $\mathrm{H}_{2} \mathrm{O}$ and IWC at $100 \mathrm{hPa}$ and try to find a linear relation. IWC is usually given in units of $\mathrm{mg} \mathrm{m}^{-3}$ and water vapor $\left(\mathrm{H}_{2} \mathrm{O}\right)$ in parts per million $(\mathrm{ppm})$ volume mixing ratio (vmr). For a better representation we use ppm units for both $\mathrm{H}_{2} \mathrm{O}$ and IWC. At $100 \mathrm{hPa} 0.1 \mathrm{mg} \mathrm{m}^{-3}$ of ice corresponds to approximately $1 \mathrm{ppm}$ of water vapor (using the ideal gas equation and mean $T$ of $195 \mathrm{~K}$ for the TTL).

Figure 5 shows scatter plots of tropical $\mathrm{H}_{2} \mathrm{O}$ and IWC at $100 \mathrm{hPa}$. The investigated regions are the entire Tropics, Indonesia, Africa and South America as highlighted in Fig. 4 (Tropics: zonal mean $8^{\circ} \mathrm{S}-8^{\circ} \mathrm{N}$, Indonesia: $12^{\circ} \mathrm{S}-$ $8^{\circ} \mathrm{N}, 100^{\circ} \mathrm{E}-170^{\circ} \mathrm{E}$, Africa: $8^{\circ} \mathrm{S}-8^{\circ} \mathrm{N}, 8^{\circ} \mathrm{W}-24^{\circ} \mathrm{E}$, South America: $8^{\circ} \mathrm{S}-8^{\circ} \mathrm{N}, 80^{\circ} \mathrm{W}-50^{\circ} \mathrm{W}$ ). Seasonal $\mathrm{H}_{2} \mathrm{O}$ and IWC data are taken and averaged longitudinally and latitudinally in each domain. The linear regression equation is added in each Figure where the anticorrelation is clearly evident. The slopes are between -0.53 for the tropical zonal mean and -1.09 for Indonesia. For a theoretical total conversion from ice to vapor and vice versa we expect a factor of -1 . The slope for Indonesia $(-1.09)$ is closest to the theoretical one and might also be the best representative, since this is the region of highest cirrus cloud occurrence throughout the year. Hence time periods of no IWC are rare and do not affect the seasonal averages. The slope for the tropical mean is lower because there are regions with much less IWC and hence the average is lower. These data clearly suggest that total water at $100 \mathrm{hPa}$ stays constant and that the temperature determines the partitioning between cirrus clouds (IWC) and water vapor.

The correlation coefficients of temperature and water vapor $\left(T, \mathrm{H}_{2} \mathrm{O}\right)$, temperature and ice water content ( $T$, IWC), water vapor and ice water content $\left(\mathrm{H}_{2} \mathrm{O}\right.$, IWC) as well as the slopes $\left(m_{\mathrm{H}_{2} \mathrm{O}, \text { IWC }}\right)$ of the regression lines of Fig. 5 and their uncertainties $\left(\Delta m_{\mathrm{H}_{2} \mathrm{O} \text {,IWC }}\right)$ are summarized in Table 1. The tabulated correlation of $\mathrm{H}_{2} \mathrm{O}$ and IWC does not represent the average of the correlation coefficients shown in Fig. 4 but instead the correlation was calculated with the averages of $\mathrm{H}_{2} \mathrm{O}$ and IWC in each region. The first and second column show that $\mathrm{H}_{2} \mathrm{O}$ and IWC are highly anticorrelated and correlated with temperature respectively. Our hypothesis of total water conservation at $100 \mathrm{hPa}$ is supported by observations over In-

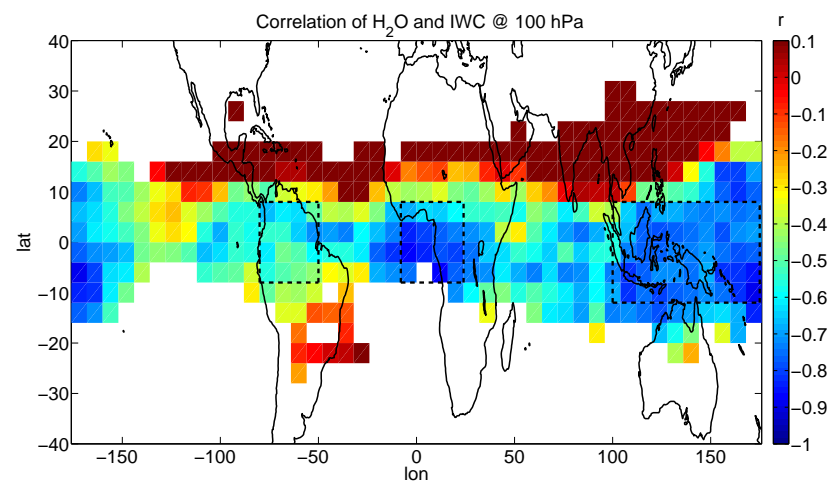

Fig. 4. Correlation map calculated with 19 seasonal data points of MLS water vapor and CALIPSO ice water content at $100 \mathrm{hPa}$ in each grid box. White areas indicate no IWC at $100 \mathrm{hPa}$. The anticorrelation is close to -1 over Indonesia and still high over Africa and South America. A band of positive correlation (red) is found in the northern subtropics, Central America, India and East Asia. The reason is a different seasonal cycle of IWC, RHi and $T$ due to a pronounced seasonal cycle of convection. The dashed boxes are the regions of interest discussed in the text.

donesia where the correlation coefficients are highest and the

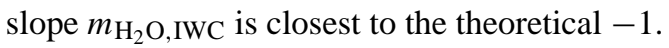

\section{Discussion}

We showed in Fig. 1 that tropical $100 \mathrm{hPa}$ temperatures determine TTL and lower stratospheric water vapor $\left(\mathrm{H}_{2} \mathrm{O}\right)$. There is a high correlation of $T$ with $\mathrm{H}_{2} \mathrm{O}(\sim 0.9)$ throughout the midlatitudes and up to $20 \mathrm{hPa}$. The temperature is also the key parameter which determines the partitioning of vapor and ice in the TTL. We anticipated that temperature acts as the regulator for the coherent water vapor and cloud variabilities by balancing the partition between water vapor and ice in cirrus clouds. A decrease in temperature increases the relative humidity which favors freezing. This hypothesis is supported by the correlation study of $\mathrm{H}_{2} \mathrm{O}$ and IWC (Fig. 4). $\mathrm{H}_{2} \mathrm{O}$ and IWC are highly anticorrelated inside the tropics with highest values over Indonesia where cirrus clouds are most abundant. Highest IWC values are directly linked to lowest $\mathrm{H}_{2} \mathrm{O}$ values (in DJF, Fig. 3). Moreover the linear regression line of seasonal IWC and $\mathrm{H}_{2} \mathrm{O}$ over Indonesia (Fig. 5) strongly suggests that total water at $100 \mathrm{hPa}$ remains constant. Hence water switches seasonally between ice and vapor. Thus the yearly decrease of about 2 ppm $\mathrm{H}_{2} \mathrm{O}$ over Indonesia from JJA to DJF translates into an increase of about $2 \mathrm{ppm}$ in IWC. This further supports that cirrus clouds to a large extent serve as a seasonal reservoir for TTL water vapor.

However, there is no anticorrelation of $\mathrm{H}_{2} \mathrm{O}$ and IWC in the $\mathrm{NH}$ monsoon regions (i.e. between $\sim 10^{\circ} \mathrm{N}$ and $\sim 20^{\circ} \mathrm{N}$, $100 \mathrm{hPa}$, red in Fig. 4). The difference of the respective 
Table 1. Correlations of $T, \mathrm{H}_{2} \mathrm{O}$ and ice water content (IWC) in different regions. Tropics (zonal mean $8^{\circ} \mathrm{S}-8^{\circ} \mathrm{N}$ ), Indonesia $\left(12^{\circ} \mathrm{S}-\right.$ $\left.8^{\circ} \mathrm{N}, 100^{\circ} \mathrm{E}-180^{\circ} \mathrm{E}\right)$, Africa $\left(8^{\circ} \mathrm{S}-8^{\circ} \mathrm{N}, 8^{\circ} \mathrm{W}-24^{\circ} \mathrm{E}\right)$, South America $\left(8^{\circ} \mathrm{S}-8^{\circ} \mathrm{N}, 80^{\circ} \mathrm{W}-50^{\circ} \mathrm{W}\right)$. The first column shows that $100 \mathrm{hPa}$ temperature and water vapor are highly correlated. $T$ and IWC are strongly anticorrelated with a smaller value over South America though. The third, fourth and fifth column show the correlation of $\mathrm{H}_{2} \mathrm{O}$ and IWC, the slope of the regression line as shown in Fig. 5 as well as the $2 \sigma$ uncertainty of the slope. The anticorrelation is high with lower values over South America. The slope in the selected regions is between -0.80 and -1.09 which is fairly close to the expected -1 if water transforms totally from ice to vapor and back.

\begin{tabular}{lccccc}
\hline Region & $T, \mathrm{H}_{2} \mathrm{O}$ & $T$, IWC & $\mathrm{H}_{2} \mathrm{O}$, IWC & $m_{\mathrm{H}_{2} \mathrm{O}, \mathrm{IWC}}$ & $\Delta m_{\mathrm{H}_{2} \mathrm{O}, \text { IWC }}$ \\
\hline Tropics & 0.94 & -0.91 & -0.91 & -0.53 & 0.06 \\
Indonesia & 0.95 & -0.84 & -0.81 & -1.09 & 0.19 \\
Africa & 0.95 & -0.85 & -0.78 & -0.80 & 0.16 \\
South America & 0.92 & -0.68 & -0.60 & -0.80 & 0.26 \\
\hline
\end{tabular}
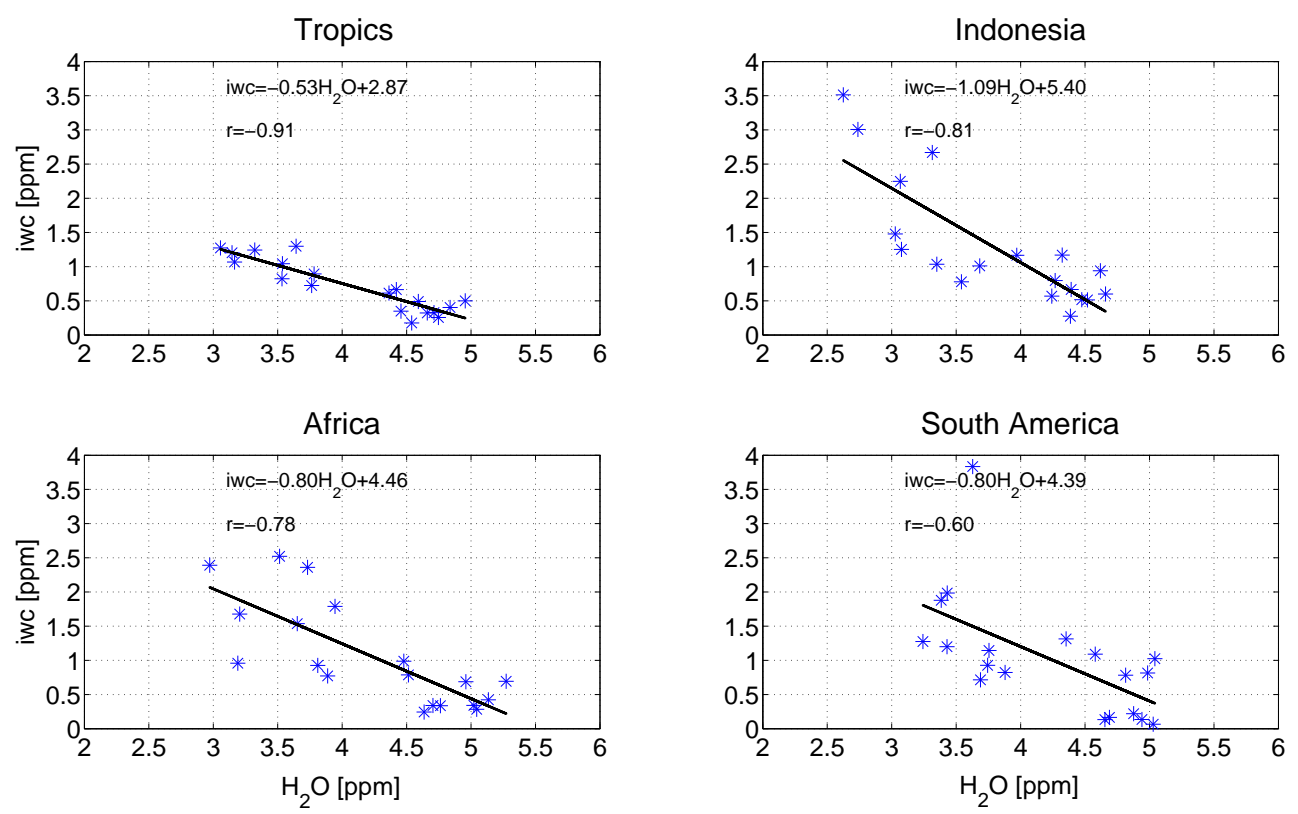

Fig. 5. Scatter plots of seasonal mean water vapor and IWC over the Tropics ( $\left.8^{\circ} \mathrm{S}-8^{\circ} \mathrm{N}\right)$, Indonesia, Africa and South America at $100 \mathrm{hPa}$. A clear anticorrelation is visible. The regression line has a slope of approximately -1 which corresponds to the total conversion of water vapor to ice in the TTL. $1 \mathrm{ppm}$ of ice corresponds to about $0.1 \mathrm{mg} \mathrm{m}^{-3}$ in the TTL. These figures suggest that total water at $100 \mathrm{hPa}$ is roughly constant in the tropics.

seasonal cycles in IWC, $T$ and RHi (relative humidity over ice) compared to the ones in the tropical band $8^{\circ} \mathrm{S}-8^{\circ} \mathrm{N}$ may explain the differences in correlation. Over the monsoon regions IWC at $100 \mathrm{hPa}$ is elevated from July to October and disappears almost entirely in DJF. This is mainly due to a more pronounced seasonal cycle of convection in the monsoon region than inside of $8^{\circ} \mathrm{S}-8^{\circ} \mathrm{N}$. Moreover there is a clear difference in the seasonal cycle of the $100 \mathrm{hPa}$ temperature between the two regions. Minimum temperatures in DJF (not shown here) are about $3 \mathrm{~K}$ lower over Indonesia and the amplitude of the seasonal cycle $(\sim 2.5 \mathrm{~K})$ is bigger than over the Indian monsoon region $(\sim 1 \mathrm{~K})$. Another difference is observed in RHi which correlates with $\mathrm{H}_{2} \mathrm{O}$ over the monsoon region but is anticorrelated over Indonesia. MLS temperatures show, that the cold point tropopause is higher over the monsoon region. During JJA it is around $85 \mathrm{hPa}$ over the Indian monsoon region whereas it is around $95 \mathrm{hPa}$ over Indonesia. In sum the results at $100 \mathrm{hPa}$ over the monsoon region (positive correlation) are similar to what is observed over Indonesia at lower altitudes $(150 \mathrm{hPa}$ for instance) because the $100 \mathrm{hPa}$ level is closer to the level of neutral buoyancy over the monsoon region and thus closer to convection. The anticorrelation of $\mathrm{H}_{2} \mathrm{O}$ and IWC is a little smaller over South America (-0.6, Table 1). This is mainly due to the absence of IWC at $100 \mathrm{hPa}$ in JJA which deteriorates the correlation. Another reason could be the influence of convection due to the limited vertical resolution of MLS $\mathrm{H}_{2} \mathrm{O}(3-4 \mathrm{~km})$. With its better vertical resolution $(\sim 1.5 \mathrm{~km}$ at $100 \mathrm{hPa}$ ) CALIOP is generally isolated from convective detrainment which occurs at pressures greater than $150 \mathrm{hPa}$. 


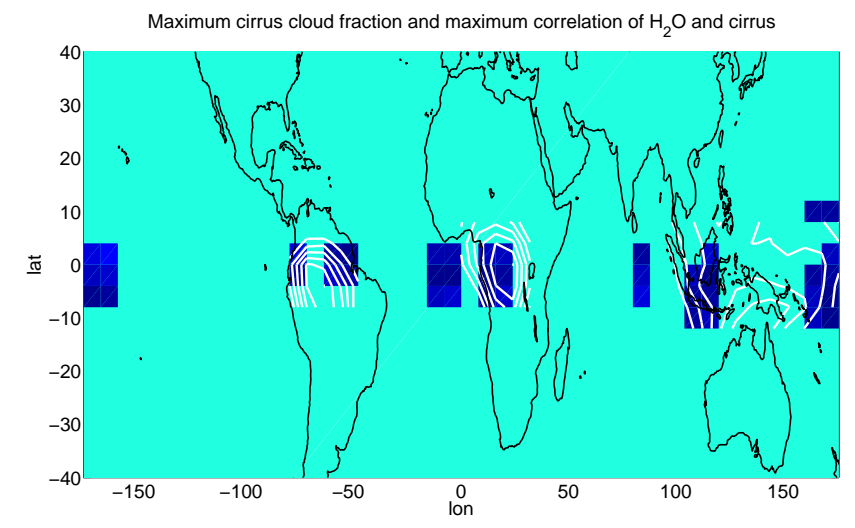

Fig. 6. Qualitative picture of the regions with maximum cirrus cloud fraction (contours) and maximum anticorrelation of water vapor and cirrus cloud fraction (dark blue rectangles). Data is averaged over the $5 \mathrm{yr}$ period. The correlation is highest off the center of maximum cirrus occurrence. Over Indonesia the regions of maximum correlation are quite symmetrical around the center of maximum cirrus fraction. We suggest that water vapor is closer to saturation in the outflow regions and a small change in temperature can produce a phase change.

This is not necessarily the case for $\mathrm{H}_{2} \mathrm{O}$ and the influence from below would tend to increase retrieved mixing ratios at $100 \mathrm{hPa}$. This influence is more pronounced over land since convection has no strong diurnal cycle over ocean (Hong et al., 2006) and would thus explain the smaller correlation of nighttime IWC and $\mathrm{H}_{2} \mathrm{O}$ over land.

We generally observe poorer correlation over land than over ocean and find that the region of highest anticorrelation of water vapor and cirrus cloud fraction is away from the regions of highest cirrus cloud occurrence as presented in Fig. 6. White contours show the $5 \mathrm{yr}$ average of cirrus cloud fraction. The data are normalized in each region and the contours show $60 \%$ to $100 \%$ of the maximum cirrus cloud fraction in each region. The same normalization is applied to the maximum anticorrelation of $\mathrm{H}_{2} \mathrm{O}$ and IWC (from Fig. 4). The highest anticorrelation for South America and Indonesia (dark blue rectangles) is found off the center of maximum cirrus occurrence. Over Indonesia it is almost symmetrically East and West of the center of maximum cirrus. Over Africa we also find a region of high anticorrelation far off the center and off the coast whilst there is still some collocation in the center.

A plausible cause for the off-center correlation is that temperature could become more potent to steer ice sublimation and evaporation in the outflow regions of the ITCZ as shown by the drawing in Fig. 7. The correlation is higher at the wings of the main convective areas than in the center where temperatures might be too low, such that a small increase in temperature is not sufficient to evaporate all the ice. Whilst in the outflow regions the air is in the vicinity of the saturation condition and a small change in temperature can induce a

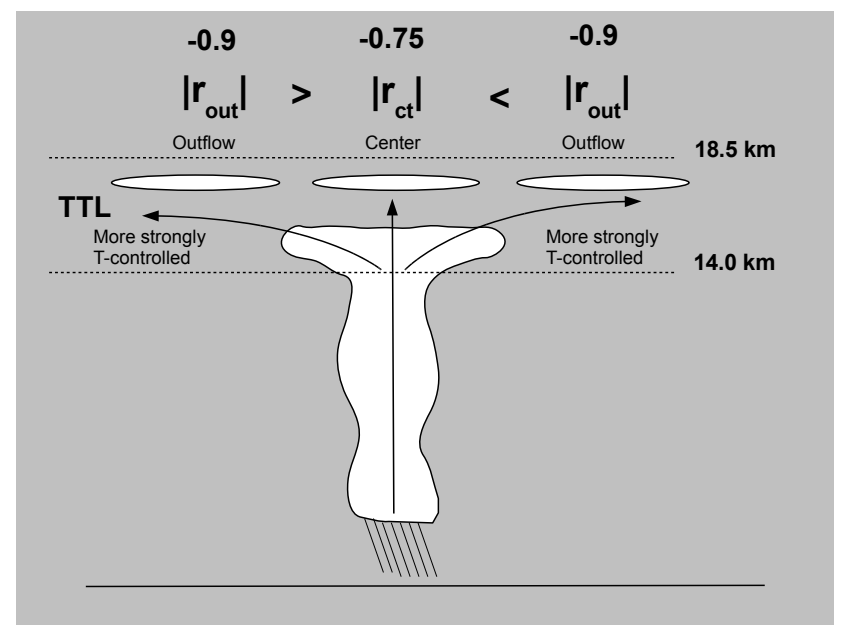

Fig. 7. Drawing of cumulus convection and cirrus formation (narrow clouds on top) inside the TTL. The anticorrelation ( $r$ ) of water vapor and cirrus is higher in the outflow regions than it is in the center of the convective region $\left(\left|r_{\mathrm{out}}\right|>\left|r_{\mathrm{ct}}\right|\right)$. Small changes of temperatures have a bigger effect on the state of water in the outflow regions therefore ice transforms to vapor and back hence the anticorrelation is high.

phase change from ice to vapor and vice-versa, resulting in a higher anticorrelation between water vapor and cirrus clouds. Thus water is more strongly controlled by temperature in the outflow regions. But even inside the main convective areas the correlation is about -0.75 which supports the hypothesis of conserved total water at $100 \mathrm{hPa}$. We will explore this idea in the future.

In sum decreasing TTL temperatures reduce the amount of water vapor to favor the increase of cirrus clouds. The question is if this is also true for decadal temperature variations? The increase in stratospheric water vapor between the last two decades before the year 2000 is still not fully understood since it was accompanied by a cooling of the tropical tropopause (Rosenlof et al., 2001). Hurst et al. (2011) report on a $0.74 \mathrm{ppm}$ increase in the layer $16-18 \mathrm{~km}$ over Boulder, Colorado $\left(40^{\circ} \mathrm{N}, 105^{\circ} \mathrm{W}\right)$ in the period $1980-2000$. Since the source of midlatitude water vapor is in the tropics we speculate that there must have been as well an increase of a comparable amount in the tropics. If our result is valid for decadal variations then a decrease in cirrus cloud fraction or IWC would have occurred along with the $\mathrm{H}_{2} \mathrm{O}$ increase during the same time period. A gain of $0.74 \mathrm{ppm} \mathrm{H}_{2} \mathrm{O}$ would roughly correspond to a loss of $0.074 \mathrm{mg} \mathrm{m}^{-3}$ IWC. We are not aware of any observations of TTL IWC from 1980 to 2000. But it would be interesting to study this change with model simulations for the observed surface temperature increase (Solomon et al., 2010) to reproduce and test the effect of reduced IWC in cirrus clouds. 
Current general circulation models poorly represent the seasonal cycle of cirrus clouds and water vapor in the TTL. Our results suggest that the tropical $100 \mathrm{hPa}$ tropopause temperature determines the balance between cirrus cloud ice and water vapor at $100 \mathrm{hPa}$ so that total water stays roughly constant. The seasonal cycle of water vapor is clearly anticorrelated with the seasonal cycle of cirrus cloud cover. There are more cirrus clouds during DJF when water vapor is low. This is a feature that is not yet represented in the GMAO GEOS-5 model (Global Modeling and Assimilation Office Goddard Earth Observing System Model, Version 5). Jiang et al. (2010) showed that the model represents the seasonal cycle of water vapor at $100 \mathrm{hPa}$ though the numbers disagree with Aura/MLS especially during JJA. But there is no clear anticorrelation with the modeled IWC. And there is also not enough IWC found in the SH tropics as suggested by CALIPSO data (Fig. 3). If this observed relationship is not well represented by model physics it will certainly add to already large uncertainty in climate predictions since TTL water vapor and cirrus clouds have significant and opposite effects on the Earth's radiation budget.

\section{Conclusions}

We calculated the correlation of Aura/MLS water vapor and temperature as well as water vapor and CALIOP cirrus cloud fraction and IWC in the tropical tropopause layer. Water vapor in the TTL and lower stratosphere is determined by the tropical $100 \mathrm{hPa}$ temperature and has a maximum correlation of 0.94 with $T$. Water vapor is transported upward and poleward following the Brewer-Dobson circulation and remains highly correlated with tropical $100 \mathrm{hPa}$ temperatures throughout the lower stratosphere from tropics to midlatitudes. The correlation of $T$ and $\mathrm{H}_{2} \mathrm{O}$ decreases rapidly above $20 \mathrm{hPa}$ due to mixing with air masses from outside the TTL and local $\mathrm{H}_{2} \mathrm{O}$ production by the oxidation of methane. The center of $\mathrm{H}_{2} \mathrm{O}$ transport is located at about $20^{\circ} \mathrm{N}$ during JJA and at the Equator during DJF. High water vapor values are distributed during JJA due to the convection in the monsoon regions, which brings a lot of $\mathrm{H}_{2} \mathrm{O}$ to $100 \mathrm{hPa}$ as can be seen in Fig. 2. Concentrations of $\mathrm{H}_{2} \mathrm{O}$ in the monsoon regions are about 1 ppm higher than at same latitudes over the Atlantic and Africa for example. Mean poleward transport is faster than upward and also faster in the Northern Hemisphere.

Furthermore, we find a high anticorrelation of $\mathrm{H}_{2} \mathrm{O}$ and cirrus cloud fraction at $100 \mathrm{hPa}$ in the tropics. The anticorrelation of water vapor and cirrus ice water content $(r=-0.91)$ suggests that total water is constant throughout the year and temperature determines the balance between water vapor and ice in cirrus clouds. A linear regression analysis of $\mathrm{H}_{2} \mathrm{O}$ and IWC shows that the slope (in $[-1.09,-0.53]$ ) encloses the theoretical slope of -1 if vapor is fully condensed into ice at $100 \mathrm{hPa}$ in the TTL. Hence the seasonal cycle of water vapor is mainly a manifestation of cirrus formation leaving the to- tal water at $100 \mathrm{hPa}$ roughly constant. In sum cirrus clouds serve as a reservoir for TTL water vapor.

Current general circulation models (e.g. GMAO GEOS-5) do not represent the anticorrelation of water vapor and ice in the TTL and need to be improved to capture this important balance correctly since cirrus and water vapor have opposite effects on global climate.

Further we find that the regions of highest anticorrelation are in the outflow regions of the main convective areas. The reason for this is supposed to be related to a different temperature which brings water vapor closer to saturation vapor pressure in the outflow regions. This is subject of ongoing work.

Acknowledgements. The work of TF has been supported by the Swiss National Science Foundation under grant PBBEP2_133505 and the National Aeronautics and Space Administration (NASA) at the Jet Propulsion Laboratory (JPL). The research by DLW and WGR was performed at JPL, California Institute of Technology under contract with NASA. Copyright 2011 California Institute of Technology. Government sponsorship acknowledged. Copyright 2011. All rights reserved.

Edited by: M. Krämer

\section{References}

Brewer, A. W.: Evidence for a world circulation provided by measurements of helium and water vapor distribution in the stratosphere, Q. J. Roy. Meteorol. Soc., 75, 351-363, doi:10.1002/qj.49707532603, 1949.

Chae, J. H., Wu, D. L., Read, W. G., and Sherwood, S. C.: The role of tropical deep convective clouds on temperature, water vapor, and dehydration in the tropical tropopause layer (TTL), Atmos. Chem. Phys., 11, 3811-3821, doi:10.5194/acp-11-38112011, 2011.

Corti, T., Luo, B. P., de Reus, M., Brunner, D., Cairo, F., Mahoney, M. J., Martucci, G., Matthey, R., Mitev, V., dos Santos, F. H., Schiller, C., Shur, G., Sitnikov, N. M., Spelten, N., Vössing, H. J., Borrmann, S., and Peter, T.: Unprecedented evidence for deep convection hydrating the tropical stratosphere, Geophys. Res. Lett., 35, L10810, doi:10.1029/2008GL033641, 2008.

de F. Forster, P. M. and Shine, K. P.: Stratospheric water vapor changes as a possible contributor to observed stratospheric cooling, Geophys. Res. Lett., 26, 3309-3312, doi:10.1029/1999GL010487, 1999.

Dessler, A. E., Palm, S. P., Hart, W. D., and Spinhirne, J. D.: Tropopause-level thin cirrus coverage revealed by ICESat/Geoscience Laser Altimeter System, J. Geophys. Res., 111, D08203, doi:10.1029/2005JD006586, 2006.

Fueglistaler, S., Dessler, A., Dunkerton, T., Folkins, I., Fu, Q., and Mote, P.: Tropical tropopause layer, Rev. Geophys., 47, 1004, doi:10.1029/2008RG000267, 2009.

Garrett, T. J., Heymsfield, A. J., McGill, M. J., Ridley, B. A., Baumgardner, D. G., Bui, T. P., and Webster, C. R.: Convective generation of cirrus near the tropopause, J. Geophys. Res., 109, D21203, doi:10.1029/2004JD004952, 2004. 
Gettelman, A., Randel, W. J., Wu, F., and Massie, S. T.: Transport of water vapor in the tropical tropopause layer, Geophys. Res. Lett., 29, 1009, doi:10.1029/2001GL013818, 2002.

Grosvenor, D. P., Choularton, T. W., Coe, H., and Held, G.: A study of the effect of overshooting deep convection on the water content of the TTL and lower stratosphere from Cloud Resolving Model simulations, Atmos. Chem. Phys., 7, 4977-5002, doi:10.5194/acp-7-4977-2007, 2007.

Hong, G., Heygster, G., and Rodriguez, C. A. M.: Effect of cirrus clouds on the diurnal cycle of tropical deep convective clouds, J. Geophys. Res.-Atmos., 111, D06209, doi:10.1029/2005JD006208, 2006.

Hurst, D. F., Oltmans, S. J., Vömel, H., Rosenlof, K. H., Davis, S. M., Ray, E. A., Hall, E. G., and Jordan, A. F.: Stratospheric water vapor trends over Boulder, Colorado: Analysis of the 30 year Boulder record, J. Geophys. Res., 116, D02306, doi:10.1029/2010JD015065, 2011.

Jensen, E. J., Pfister, L., Bui, T.-P., Lawson, P., and Baumgardner, D.: Ice nucleation and cloud microphysical properties in tropical tropopause layer cirrus, Atmos. Chem. Phys., 10, 1369-1384, doi:10.5194/acp-10-1369-2010, 2010.

Jiang, J. H., Su, H., Pawson, S., Liu, H.-C., Read, W. G., Waters, J. W., Santee, M. L., Wu, D. L., Schwartz, M. J., Livesey, N. J., Lambert, A., Fuller, R. A., and Lee, J. N.: Five year (20042009) observations of upper tropospheric water vapor and cloud ice from MLS and comparisons with GEOS-5 analyses, J. Geophys. Res., 115, D15103, doi:10.1029/2009JD013256, 2010.

Liang, C. K., Eldering, A., Gettelman, A., Tian, B., Wong, S., Fetzer, E. J., and Liou, K. N.: Record of tropical interannual variability of temperature and water vapor from a combined AIRS-MLS data sets, J. Geophys. Res., 116, D06103, doi:10.1029/2010JD014841, 2011.

Mote, P. W., Rosenlof, K. H., McIntyre, M. E., Carr, E. S., Gille, J. C., Holton, J. R., Kinnersley, J. S., Pumphrey, H. C., Russell, III, J. M., and Waters, J. W.: An atmospheric tape recorder: The imprint of tropical tropopause temperatures on stratospheric water vapor, J. Geophys. Res., 101, 3989-4006, doi:10.1029/95JD03422, 1996.

Plumb, R. A.: A “tropical pipe” model of stratospheric transport, J. Geophys. Res., 101, 3957-3972, doi:10.1029/95JD03002, 1996.

Randel, W. J., Wu, F., Oltmans, S. J., Rosenlof, K., and Nedoluha, G. E.: Interannual Changes of Stratospheric Water Vapor and Correlations with Tropical Tropopause Temperatures, J. Atmos. Sci., 61, 2133-2148, doi:10.1175/15200469(2004)061<2133:ICOSWV>2.0.CO;2, 2004.

Read, W. G., Lambert, A., Bacmeister, J., Cofield, R. E., Christensen, L. E., Cuddy, D. T., Daffer, W. H., Drouin, B. J., Fetzer, E., Froidevaux, L., Fuller, R., Herman, R., Jarnot, R. F., Jiang, J. H., Jiang, Y. B., Kelly, K., Knosp, B. W., Kovalenko, L. J., Livesey, N. J., Liu, H.-C., Manney, G. L., Pickett, H. M., Pumphrey, H. C., Rosenlof, K. H., Sabounchi, X., Santee, M. L., Schwartz, M. J., Snyder, W. V., Stek, P. C., Su, H., Takacs, L. L., Thurstans, R. P., Vömel, H., Wagner, P. A., Waters, J. W., Webster, C. R., Weinstock, E. M., and Wu, D. L.: Aura Microwave Limb Sounder upper tropospheric and lower stratospheric $\mathrm{H}_{2} \mathrm{O}$ and relative humidity with respect to ice validation, J. Geophys. Res., 112, D24S35, doi:10.1029/2007JD008752, 2007.
Read, W. G., Schwartz, M. J., Lambert, A., Su, H., Livesey, N. J., Daffer, W. H., and Boone, C. D.: The roles of convection, extratropical mixing, and in-situ freeze-drying in the Tropical Tropopause Layer, Atmos. Chem. Phys., 8, 6051-6067, doi:10.5194/acp-8-6051-2008, 2008.

Rosenlof, K. H., Chiou, E.-W., Chu, W. P., Johnson, D. G., Kelly, K. K., Michelsen, H. A., Nedoluha, G. E., Remsberg, E. E., Toon, G. C., and McCormick, M. P.: Stratospheric water vapor increases over the past half-century, Geophys. Res. Lett., 28, 1195-1198, doi:10.1029/2000GL012502, 2001.

Schneider, T., O'Gorman, P. A., and Levine, X. J.: Water vapor and the dynamics of climate changes, Rev. Geophys., 48, RG3001, doi:10.1029/2009RG000302, 2010.

Schoeberl, M. R., Douglass, A. R., Stolarski, R. S., Pawson, S., Strahan, S. E., and Read, W. G.: Comparison of lower stratospheric tropical mean vertical velocities, J. Geophys. Res., 113, 24109, doi:10.1029/2008JD010221, 2008.

Schwartz, M. J., Lambert, A., Manney, G. L., Read, W. G., Livesey, N. J., Froidevaux, L., Ao, C. O., Bernath, P. F., Boone, C. D., Cofield, R. E., Daffer, W. H., Drouin, B. J., Fetzer, E. J., Fuller, R. A., Jarnot, R. F., Jiang, J. H., Jiang, Y. B., Knosp, B. W., Krüger, K., Li, J.-L. F., Mlynczak, M. G., Pawson, S., Russell, J. M., Santee, M. L., Snyder, W. V., Stek, P. C., Thurstans, R. P., Tompkins, A. M., Wagner, P. A., Walker, K. A., Waters, J. W., and $\mathrm{Wu}, \mathrm{D}$. L.: Validation of the Aura Microwave Limb Sounder temperature and geopotential height measurements, J. Geophys. Res., 113, D15S11, doi:10.1029/2007JD008783, 2008.

Solomon, S., Rosenlof, K. H., Portmann, R. W., Daniel, J. S., Davis, S. M., Sanford, T. J., and Plattner, G.-K.: Contributions of Stratospheric Water Vapor to Decadal Changes in the Rate of Global Warming, Science, 327, 1219-1223, doi:10.1126/science.1182488, 2010.

Wang, P.-H., Minnis, P., McCormick, M. P., Kent, G. S., and Skeens, K. M.: A 6-year climatology of cloud occurrence frequency from Stratospheric Aerosol and Gas Experiment II observations (1985-1990), J. Geophys. Res., 101, 29407-29430, doi:10.1029/96JD01780, 1996.

Winker, D. M., Hunt, W. H., and McGill, M. J.: Initial performance assessment of CALIOP, Geophys. Res. Lett., 34, 19803, doi:10.1029/2007GL030135, 2007.

Wu, D. L., Chae, J. H., Lambert, A., and Zhang, F. F.: Characteristics of CALIOP attenuated backscatter noise: implication for cloud/aerosol detection, Atmos. Chem. Phys., 11, 2641-2654, doi:10.5194/acp-11-2641-2011, 2011.

Yang, Q., Fu, Q., and Hu, Y.: Radiative impacts of clouds in the tropical tropopause layer, J. Geophys. Res., 115, D00H12, doi:10.1029/2009JD012393, 2010. 